\title{
Cooking up a Course: Teaching sustainable marketing at MBA
}

\author{
Ynte K. VAN DAM \\ Wageningen University \& Research, The Netherlands
}

\begin{abstract}
:
Aim: To explore how a critical course on mainstream marketing and business theory can shift the perception of sustainability as an extrinsic goal to sustainability as an intrinsic boundary condition to business.

Design/Method: An introductory course is designed in which a system approach is introduced by assessing the purported marketing purposes of the firm relative to an increasing range of manifest and latent stakeholders. Key elements of the course are received elements of MBA programs to illustrate that education for sustainability does not mean teaching new topics, but means a new way to teach old topics.

Finding: It is shown that the course meets the requirements and recommendations that were derived from theory on teaching sustainability in higher education. Though the topics and theories covered are central to a mainstream MBA program, the way they are presented and questioned promotes learning critical thinking by doing. The long term effects of this approach cannot yet be tested, and require longitudinal research among participants and teachers of the consecutive courses

Originality: Within the boundaries of mainstream MBA the course invites critical reflection of established theories from a sustainability perspective. Being presented as the foundation of an MBA program sustainability is offered as a boundary condition for corporate management,.
\end{abstract}

Key words: sustainable marketing; education; $M B A$

$J E L: A 2, D 4, M O$

Correspondence address: Ynte K. VAN DAM, Wageningen University and Research, The Netherlands. Email: ynte.vandam@wur.nl

Received: 06.05.2019, Accepted: 05.07.2019

doi: http://dx.doi.org/10.29015/cerem.827 
Sustainability is not a goal but a way to travel

\section{Introduction}

The concept of sustainable economic development was introduced in 1987, but the "sustainable shift" is slow to reach academic marketing education. Even though sustainability related skills are viewed as increasingly important for managers (Fisher, Bonn 2017), academic business programs are reluctant to adopt sustainability related content and only a small portion of marketing courses is devoted to sustainability education (Barber et al. 2014; Fisher, Bonn 2017; Friel, McLaughlin 2013; Perera, Hewege 2016). Especially business schools tend to base their programs on a businesscentred worldview in which the success of society depends on the success of companies (Beddewela et al. 2017) and in which the success of companies equals profit. For decades international business schools have focused on the shareholder model that reduces the success of companies to quarterly financial returns and stock market value (Barber et al. 2014; Exter et al. 2013). In this model the truism that the long term survival of a company in a market economy requires it to be profitable has been turned around - making profitability and superior financial performance the main purpose of the company (Hunt, Morgan 1995; Kotler 1994). As a result cost saving and value appropriation are promoted at the cost of viability and value creation (Mouzas 2006). Consequently business schools are notorious for training prospective managers in using amoral linear models of growth, efficiency, selfishness, and greed (Capra, Luisi 2014; Koris et al. 2017; Örtenblad et al. 2013). These models may reflect the values of an industrial worldview (Thévenot 2001), but the single-minded focus on efficiency and short-term profitability does not educate managers in critical thinking nor in ethical reflection on the company's processes that are vital for successful market performance in a changing environment (Alvesson, Spicer 2012; Beer 1981; King 1985; Palazzo et al. 2012).

For decades there has been little evidence of wider moral, societal, and political issues in the marketing curricula (Turnquist et al. 1991). Though some business students may adhere to sustainable values in their daily life (Ng, Burke 2010), they do not see ethics as relevant for entrepreneurship (Wilhelm 2002) and they have noteworthy little opportunity to apply these values as doctoral students in marketing 
or business (Wilkie, Moore-Shay 1997). The growing need for managers in sustainable, conscientious, and/or ethical companies should provoke business schools to reconsider not only their educational program but also their role in society (Kurucz et al. 2014), as reflected in the latest AACSB/ACBSP guidelines (Nicholls et al. 2013). This notwithstanding a critical reflection on the myopic profit focus of existing MBA-marketing programs may still be a certain way out of a business school career (Ehrensal 1999). Therefore the most common way to navigate the conflicting demands of the Anglo-Saxon and the critical business model in education therefore is bolting ethical and sustainable topics onto existing programs (Snelson-Powell et al. 2016). In practice this "end-of-pipe solution" implies paying occasional lip service to sustainability or ethics during mainstream courses, and topping off the finished program with a specialised ethics and sustainability course at the end. Bolted-on sustainability is succinctly reflected in some best-selling marketing textbooks (Kotler et al. 2013; Kotler, Keller 2016). In this way ethics and sustainability are effectively presented as external limitations that prevent some, otherwise highly attractive, marketing practices. At best this teaches students about sustainability and ethics, but at worst this provokes a legalistic approach to sustainability and ethics, culminating in the attitude that "anything that is not illegal is acceptable" (Schwartz 2012).

In the current paper the outline of an inclusive introduction of sustainability in higher business education is reported. Contrary to the bolted-on approach, an inclusive approach to teaching for sustainability requires weaving sustainability and ethics through every aspect of the curriculum (Snelson-Powell et al. 2016). Because a market orientation is key to business success a sustainable marketing orientation should be the key to sustainable business. Inclusive teaching of sustainable marketing should invite continuous reflection on the societal impact of marketing and on the limitations of marketing (Mitchell et al. 2010; Van Dam, Apeldoorn 1996). Therefore the "Leitmotiv" of this course is critical reflection on, and critical assessment of, the (lack of) sustainability of contemporary business and of the theories by which this is legitimised. 


\section{On recipes, cooking, and cookery}

There is no single accepted methodology for teaching sustainability in higher education, though the need for integrating multidisciplinary sustainability teaching in university classrooms is hardly disputed (Schneiderman, Freihoefer 2009). It has been suggested that "how" critical sustainable reflection is taught is at least as importance as "what" is taught (Robinson 2009; Schneiderman, Freihoefer 2009). Various learning models aim at challenging students' preconceptions and raising uncertainty and ambiguity, in order to prepare students for developing fresh insights and understanding (Robinson 2009). Common denominators of several existing teaching methods are disenchanting, empowering, and system-oriented: disenchanting by identifying and critically reflecting on the assumptions, the paradigms, and the power relations that define the domain being studies; empowering by participatory, handson, direct training of relevant skills; and system-oriented by stressing the multidisciplinary interconnectedness of different viewpoints on contextual issues (Alvesson, Sandberg 2011; Burns 2009; Robinson 2009; Schneiderman, Freihoefer 2009). These teaching methods confront the students with critical perspectives that question dominant paradigms and hidden assumptions of the students in a participatory and experiential process (Burns 2009; Muijen 2004).

Education for sustainability should be built on various ingredients - like, e.g., systemic and holistic thinking, integration of different perspectives, self-transcendent values - translated into a range of skills that are required for critical and systems thinking, and for effective communication and collaboration (Svanström et al. 2008; Tarrant, Thiele 2016; Wals 2012). Turning these ingredients into a palatable mix of learning processes, philosophical and ethical perspectives, sustainability issues, didactics, and practical content has been likened to cooking (Muijen 2004). In cooking a recipe provides the instructions for preparation, but the hands of the cook and the quality of the ingredients are indispensable for a successful result. Maybe the better metaphor for teaching is not cooking but cookery, where recipes are not instructions but mere suggestions how ingredients may be handled and combined. Cookery is meant to trigger rather than confine the cook's imagination (Leyel, Hartley 1925). Likewise a course on sustainable marketing systems should trigger the imagination of 
the student to appreciate that every experience or every event is part of the environing world within a unique temporal and situational context (Dewey 1938; Tarrant, Thiele 2016). Likewise, as befitting a recursive system, any course on sustainable marketing is embedded in its own specific and unique situational context and the ideas presented here are mere suggestions to trigger rather than confine the imagination of the reader in cooking up a course on critical sustainable marketing.

The aim of sustainable higher education should not be to train dogmatic followers of critical theory, but to train critical users of mainstream theories (Alvesson, Sandberg 2011; Svanström et al. 2008). The guiding principle in teaching critical science is that critical thinking is learned by doing and not by reading about it (Tarrant, Thiele 2016). Of course it would be easy to combine the vast body of literature on critical marketing and critical management as required reading for students (see, e.g., Alvesson et al. 2009; Grey, Willmott 2005; Saren et al. 2007; Tadajewski, Brownlie 2008). Like in many other instances the effectiveness of such easy approaches is to be doubted as they often tend to be neat, plausible, and wrong (Mencken 1921). In the cookery approach therefore the instructor absorbs this body of critical literature and applies the acquired insights in teaching mainstream material. The critical twist is not in the ingredients but in their preparation and presentation, making students not only question the assumptions behind the mainstream models that are offered, but behind all management conventions they will meet in the career (Alvesson, Sandberg 2011). Rather than teaching different material in the traditional way, the instructor is challenged to teach traditional material in a different way.

\section{Seasoning: critical marketing}

Mainstream marketing education is being challenged for unquestioningly propagating and replicating the non-sustainable economic status quo (Tadajewski 2010b). Likewise many business schools are accused of delivering foot-soldiers to corporate capitalism (Ehrensal 2001) and of socialising students into exemplary managers of an imaginary ideal corporation (Smith 1994). Reflection on the implications of marketing to society may once have been the evident focus of 
marketing education, as marketing and management were viewed as means to achieve societal goals (Priddle 1994). Nowadays it is taken for granted that these implications are beneficial by definition and marketing management is viewed as an end in itself. Therefore critical reflection on marketing is reduced to the issue of how students are best trained in marketing (Hyman 2004).

Marketing education that critically questions this status quo is gradually regaining popularity (Tadajewski 2010a) and various approaches to facilitate critical thinking in marketing education are being advocated (Barber et al. 2014; Borin, Metcalf 2010; Jonson et al. 2015; Roy, Macchiette 2005; Wieland, Fitzgibbons 2013). Still, the idea of critical marketing in a business program easily deters a majority of students, teachers, and program directors. This is caused at least partly by the ambiguous meaning of "critical" in education (Burton 2001).

In the popular vernacular being "critical" has the dual meaning of "expressing adverse and disapproving judgements" as well as "being in a state of a crisis and transition". In this popular interpretation "critical marketing" suggests that marketing has a deplorable character and/or is on the verge of collapse. This view is reinforced by radical calls for a stop to teaching business students any theories or models that can be traced back to neo-classical economics and neo-liberalism, because they are antithetical to sustainable development (Wymer, Rundle-Thiele 2017). This strong definition of critical marketing education is poorly compatible with business programs as it would disqualify most, if not all, existing marketing models for teaching and disqualify most graduates for employment. This "popular criticism" obviously is not what is meant by "critical" in a (marketing) education program.

A weak definition of critical marketing education explains "critical thinking" as a process of "analysing merits and limitations". This weak definition of critical thinking can be equalled to sophisticated forms of learning such as analysis, synthesis, and evaluation. Skills for critical thinking include being able to identify, analyse, evaluate and present arguments, and being able to distinguish fact from judgment and knowledge from belief (Roy, Macchiette 2005). These skills are trained by exercises in debating and by discussing contrary perspectives to improve intellectual standards - such as accuracy and clarity of argumentation, logical thinking, finding supporting and contrary evidence, and fairness. This type of critical academic reflection should 
be a basic component of any academic training, though its presence apparently is not self-evident in marketing and business programs (Wilkie 2016).

Critical theory in marketing and management goes beyond mere academic reflection, but stops well short of creatively destroying marketing as an academic discipline. Critical theory implies questioning the assumptions of marketing and revising these were possible (Alvesson, Sandberg 2011), allowing one to continuously rebuild and redesign one's knowledge while simultaneously using it to understand and explain reality (Hempel 1980; Neurath 1932; Tadajewski 2010a). Critical theory commonly combines reflection on fundamental assumptions with empowerment and emancipation (Mezirow 1981; Spicer et al. 2009). As such critical theory is easily equated to neo-Marxism, feminism, post-structuralism, and a host of other nonpositivist positions (Fournier, Grey 2000). This easy equation misses the point that non-positivist and critical science only partially overlap, and that the dogmatic rejection of (post)positivist science is equally non-critical as the dogmatic adoption of either positivism or neo-Marxism (Alvesson, Sandberg 2011; Fournier, Grey 2000).

Over the past decades the traditions of higher education have been challenged by competence based learning (Brooks 2009; Hyland 1993a, 1993b; Tarrant 2000). With respect to sustainable development in higher education a set of "key competencies" are assumedly critical for sustainability (for an overview see, e.g., Wiek et al. 2011). Though willing to acknowledge that any qualified graduate must master competencies, one may doubt whether everyone trained in these competences should qualify as graduate. Competence based learning is in itself a paradox (Campbell 1976), but in relation to sustainable development doubly so. Acknowledging the need for a non-reductionist systems approach competence based education responds mechanistic-reductionist with offering an ubiquitous toolkit (Lester, Religa 2017; Tarrant 2000). Rooted in (anti-positivistic) social constructivism and phenomenology competence based education emerges as social engineering towards the positivistic outcome of real and known sustainability. And by focussing on competencies rather than the propaedeutic knowledge it may well deliver incompetent graduates (Brooks 2009; Grant 1999). The myopic focus on sustainability-competences has neutralised the emancipatory and transformational potential of critical science. Devoid of theoretical or epistemic background competence based learning has turned critical 
thinking in a management tool for the improvement of individual and corporate behaviour vis-a-vis a deteriorating environment (Velasco Arias 2019).

Critical reflection in marketing education aims at rendering visible the assumptions under existing theory and models. Empowerment in marketing aims at acting on these insights to transcend the structural conditions that limit marketing executives to the replication of existing undesirable patterns of behaviour. Critical reflection on marketing is not new to academia, but critical empowerment of graduates appears to be lacking. Marketing as a discipline is based upon many assumptions that are questionable, and these assumptions have been questioned for decades with regrettably few implications for teaching, research, or publishing (Burton 2001). Many of these questionable assumptions are directly related to the lack of sustainability in mainstream marketing (Jamrozy 2007), and to be viable within sustainable development marketing might be better off without blind adherence to these assumptions. This notwithstanding many academics implicitly or explicitly hold on to these assumptions, and routinely disseminate them as axioms to new generations of marketing graduates and marketing practitioners (Phelan 2006).

\section{The Course}

\subsection{POSIWID and the purpose of the firm}

Reflection on the assumptions of marketing in relation to the societal impact of marketing has generally been relegated to the domain of macromarketing (Hunt 1976; Priddle 1994). In macromarketing a system theoretic approach is being recommended for the study of marketing systems and market behaviour within a societal context composed of various stakeholders in an institutional environment (Arndt 1981; Carson et al. 1999; Fisk 1967; Layton 2007, 2015; Vargo 2011). In line with the systems view on marketing the implicit guideline used in this critical course on marketing systems is the cybernetic dictum "the purpose of a system is what it does" (POSIWID, see: Beer 2002). We can describe the marketing system from many angles, and we can describe individual firms as partially autonomous systems that operate within the marketing system. For each of these systems the dictum holds that 
the purpose of that system is what it does. This POSIWID dictum is the guiding principle in problematising marketing and management (Alvesson, Sandberg 2011). Defining the purpose of the system as "what it does" distinguishes a system and its manifest purpose from the aim, goal, intent, or objective of the people who designed and/or are using that system. This avoids deontological or teleological moral judgements of the system, and allows a positive discussion of differences in observed purpose due to different perspectives. In this discussion claims on "what the system does" can and should be backed up with empirical evidence. If observed outcomes are deemed undesirable, understanding these outcomes as purposes rather than as sideeffects of a system may facilitate the identification of their systemic causes. At the same time it should be noticed that what a complex (social) system does, and more specifically what that system does relative to each of its components and its environment, usually is a matter of unfolding perspective. Both the boundaries of a social system and the scope of the observed outcomes are not self-evident, and complex systems will generate an array of, sometimes conflicting, outcomes. Some of these outcomes only become manifest over time, and some of these outcomes result from interactions and frictions in an overarching metasystem. It very well may be impossible to know the full purpose of a complex system, but that merely means that understanding complex systems is an ongoing process.

The purpose of a firm, or the purpose of a marketing system, is not what it is meant to do, not what it is claimed to do, not what it ideally could do, but merely and exclusively what it does. Without further specification this purpose only can be formulated in general (prototypical and/or stereotypical) terms that are mostly confined to the internal machinations of the system and the hypothetical analysis of its external impact. What a system does relative to its environment only can be known when a specific system is studied in the situational context of its actual environment. As soon as different real existing marketing systems or a real existing firms are discussed the analytical focus can shift to comparative analysis of these systems and of the impact of these systems on their environment.

Within the firm the employee adapts his or her behaviour to the perceived purpose of the firm (Alvesson, Willmott 2002). What the employee does, i.e. the purpose of the employee, makes sense given the purpose of the firm, as unfolded to this 
employee. Likewise the purpose of the firm, i.e. what the firm does, makes sense given the purpose of the marketing system, as unfolded to this firm. And the purpose of the marketing system makes sense given the purpose of its social and institutional environment. Each of these consecutive levels of analysis may cast a different light on the perceived purpose of the firm. Therefore analysing the purpose of the firm at different levels of abstraction and from different angles, should change the perception of the purpose of the firm and thus of the appropriate behaviour of the employee.

Most of the salient assumptions that dominate mainstream marketing management are derived from those Chicago School economists who equal efficiency to effectiveness in achieving wealth and justice (Posner 2007), or who confine the purpose of business to maximising profit and creating shareholder value (Friedman 1962). This was worded concisely by a student as "the purpose of the company is to make money, and my purpose in the company is to count money". This focus on the orthodox (neo)classical economic assumptions of profit maximisation is central to Western management (Mamman, Saffu 1998), although these assumptions have been dropped throughout most of institutional economy and organizational theory (Williamson 2002). Rather than challenging this core assumption head-on (Baden, Higgs 2015), it can be taken as a point of departure and narrowed down by shifting to the individual perspective. After all, not many people will explain their profession as "I maximise my income in a company that maximises profit".

In order to recoup its costs and in order to generate an income a company has to exchange its products and/or services for money in the market. Successful or profitable financial performance therefore requires successful market performance (Hunt, Morgan 1995, 1996). The actual market behaviour of a company reflects a range of legitimate strategic and tactical choices that embody the company's valuepropositions relative to an identified market. The marketing goal of the company can be explained as achieving differential competitive advantage, i.e. a unique position relative to competitors. This competitive advantage is based on the unique access to (a combination of) resources (Hunt, Morgan 1995; Hunt 1997a). Unique and differential access to resources leads to asymmetric market opportunities that result in differential competitive advantage for companies within a marketing system (Hunt, Morgan 1996; Hunt, Davis 2008; Thévenot 2001). The differential resource advantage 
of companies can be enhanced by technological development, but it is an ideological and strategic choice whether this technical development is focused on lowering the costs of resources and production processes or on increasing the value that is created and offered to customers (Habermas 1968; Kim et al. 2016; Porter 1985; Thévenot 2001). The resource advantage theory of competitive advantage offers a pragmatic understanding of marketing that exceeds the operational managerial perspective, by explicitly distinguishing between managing costs or efficiency and managing value or effectiveness to gain competitive advantage (Fearne, Fowler 2006; Hunt, Morgan 1996; Mouzas 2006). The market goal of the company may be competitive advantage, but the purpose of the firm is what it does, and when it is perceived to "make money" - that is the perspective that shapes the behaviour of the employees.

Shifting this perspective can change the behaviour of employees. Therefore it matters whether a company is seen to make profit by lowering its resource costs or by increasing the value that is added to its resources. It further matters whether lower resource costs are framed as efficiency, as exploitation, or as ephemeral profit, just like it matters whether higher added value is framed as effectiveness, as exploration, or as unprofitable growth.

\subsection{The resources and strategies of the firm}

The issue of differential access to resources could invite a more in-depth discussion around the observation that resources are not to be viewed as tangible and given (Peach, Constantin 1972; Zimmermann 1933, 1951). Resources are not tangible, because it is not the "thing or the substance" but the function that it may perform or the operation in which it takes part that constitutes the resource. Resources are not given, because anything is neutral until people find a way to extract a service from it (Peach, Constantin 1972; Vargo, Lusch 2004). Resources are appraisals of affordances that are recognised in the environment. Technological and social developments allow virtually anything to become a resource, and it may remain a resource as long as it embodies a valued service. Many valued services are not embodied in natural resources, but in access to institutions. Eventually access to all resources is mediated by human beings and their labour, skills and abilities, decision power, goodwill, willingness to exchange, or spending power. Discussing the fluidity 
of resources along these lines opens the way to both resource advantage theory and service dominant logic in marketing, and to the insight that innovation is not creating new products, but identifying new resources (Hunt 1997a; Vargo, Lusch 2004).

At least up to the 1960s it was self-evident that the value and legitimacy of marketing functions in the firm depend on their ability to embody and social services (Cox 1962 as cited in: Priddle 1994). Since the 1980s market growth and/or superior financial performance increasingly have become an end in itself (Hunt, Morgan 1995; Hunt, Davis 2008). Implicitly or explicitly this reduction of (social) corporate legitimacy to (private) financial goals is endorsed by all leading marketing textbooks. The reduction of social legitimacy to profitability affects the strategic decision whether to focus on added value or on resource costs in the quest for differential competitive advantage. Lower resource costs and higher added value both may increase the value-for-money that is offered to customers and the return on investment that is available for shareholders (Hunt 1997a), but the dominant focus determines whether a market will converge on price competition or on quality competition. If profitability is a sufficient condition for legitimacy, there is no normative distinction between a race-to-the-bottom and a climb-to-the-top in terms of product quality and/or sustainability (Ellickson 2006; Mosley, Uno 2007; Overton et al. 2012).

The didactic goal of critical marketing education should not be to challenge the validity of this reduction head-on, but to make students question the assumptions that legitimise this reduction and that encourage companies to change their purpose from "offering solutions" through "selling products" into "making money". In systems theory the behaviour of a subsystem is explained by its place and its function within the higher level system, like the behaviour of an employee within a firm. Questions about the assumptions that explain the subsystem "firm" therefore requires shifting one level up to the purpose of the market.

\subsection{The purpose of the market system}

It might very well be that as long as one is concerned with firms and markets in general and with infinite numbers of abstract and anonymous actors the neo-classical perfect competition among self-interested actors is an adequate model of the market. Speaking about specific firms in specific contexts the basic assumptions of neo- 
classical perfect competition increasingly fail to predict market behaviour. The key assumptions of resource advantage theory of competition may provide a superior explanation for both the micro-economic behaviour of firms and the macro-economic development of markets (Hunt, Morgan 1995; Hunt 1997a, b).

Even if the purpose of the firm is to make money or to maximise profit, it usually will not aim for a one-off performance in the market. Missing therefore is the most fundamental objective of a firm: to reproduce its position in a specific marketing system. One way to reproduce one's position is by being a necessary component of the marketing system. This requires adjusting the firm's processes to serve the purpose of the marketing system. Another way to safeguard one's position could be by dominating and controlling the marketing system. This requires adjusting the purpose of the marketing system to make it serve the firm. Both require some understanding of the purpose of the marketing system and of the processes that govern the marketing system in its development.

Marketing systems are complex networks of individual and corporate actors that are connected by their shared participation in value creation through exchange (Layton 2015). Marketing systems typically follow a regular pattern of development from the trial-and-error economic offerings of individual entrepreneurs to the autonomous growth of a self-organising complex system that purges these entrepreneurs. Because these complex marketing systems develop and prosper in their situational context, they only can be understood by focusing on a specific marketing system in relation to its specific context. Adapting a definition from Layton (2007), each marketing system can be thought of as:

1. A network of individuals, groups and/or entities

2. That is embedded in a social matrix

3. Linked directly or indirectly through sequential or shared participation in the exchange of social and/or economic value

4. Which jointly creates, assembles, transforms and makes available

5. Assortments of products, services, experiences and ideas

6. Provided in response to or anticipation of customer demand.

In this definition, a marketing system primarily has a social function of offering assortments that enhance wellbeing and welfare of its stakeholders (Layton 2015). 
Several limitations to this definition should be noted. One is that the purpose of a marketing system is what it does, and wat it does is may be different from its alleged social function. Another is that the firm operates in many markets that are not covered by this definition. Firms operate in a financial market for insurance, documentary credit, hedging, foreign currency, investors, speculation, and other financial services. Firms operate in a labour market for hiring, training, and outplacing employees. Firms operate in a media market for image management, promotion and otherwise influencing public opinion. Firms interact with a wide variety of stakeholders in different markets or non-market contexts and firms interact with different stakeholders in different ways.

Formulated differently firms coordinate their behaviour with a range of stakeholders in different ways. The next steps therefore should introduce both stakeholder theory and governance before reaching social costs and sustainable market performance.

\subsection{Systems of stakeholders}

The marketing management of leading schools is grounded in the shareholdercentric Anglo-American governance systems (Epstein 2012). One of the consequences is that other stakeholders receive little attention (Kotler, Keller 2016), and this attention is mainly focused on the impact of these stakeholders on shareholder value. A more extensive approach acknowledges a wide range of different stakeholders that can be classified in terms of their defining attributes - power, legitimacy, and urgency (Mitchell et al. 1997). These attributes provide stakeholders with the ability (power), opportunity (legitimacy), and motive (urgency) to act upon a company. Depending on the presence or absence of one or more of these defining attributes eight categories of stakeholders have been identified (Mitchell et al. 1997), ranging from disregarded stakeholders that have none of the defining attributes to definite stakeholders that combine all. It is a highly instructive exercise to differentiate these eight categories of stakeholders and spend considerable effort to identify as many groups as possible in each category. Though it may be tempting to focus all attention on definite, dangerous, and dominant stakeholders in the centre of the model (cf. Kotler, Keller 2016), it could become evident that the largest number of groups 
are found to the periphery of the model. Many different publics are characterised by only one defining stakeholder attribute, rendering them latent stakeholders. Each of these publics may build alliances with other latent stakeholders. More often than not "the likes will attract" and uniting stakeholders within a category on a common cause will not change their defining attributes. However, once latent stakeholders with different attributes are joined in a cross-category alliance their claim on a company may become a force to be reckoned with.

A cross-category union of latent stakeholders may manifest itself in many ways. A most constructive way is the creation of alternative provision systems and/or alternative marketing systems. Apple computers, Linux software, organic produce, and Fair trade are some notable results of the union of urgency with power and legitimacy among publics that were ignored by a seemingly incontestable marketing system dominated by unassailable firms. Less constructive may be (class-action) lawsuits, boycotts, protests, or other punitive actions against a firm. More in general the indiscriminate externalisation of costs to publics that can be ignored sooner or later may turn these disregarded stakeholders into demanding or discretionary stakeholders.

One of the most disregarded stakeholders may well be the planet itself. Having been a sink of industrial waste since the dawn of industrialisation it gradually gains urgency in terms of climate change and loss of biodiversity. Once these processes pass a tipping point they also gain the power to affect business performance. Though companies have found their way to deal with dangerous stakeholders, once the ecosystem shifts from a demanding to a dangerous stakeholder it may prove impossible to bargain with it.

\subsection{Governance systems}

Within the boundaries set by the institutional environment, firms and markets are viewed as different types of governance system for the coordination of economic transactions (Coase 1937; North 1984; Powell 1990; Williamson 1995). The classical distinction between internal coordination within firms and external coordination by markets (Coase 1937) has been expanded into a two dimensional space in which (topdown) hierarchy is opposed to (bottom-up) autonomy, and in which atomistic 
competition is opposed to relational cooperation (Deshpandé et al. 1993). It should be noted that these governance dimensions are related to distinct regulatory styles and distinct motivations (Deci, Ryan 1985, 2000, 2008; Ryan, Deci 2000; Van Dam, Van Trijp 2016). This two dimensional space allows for a the classification of range of alternative governance styles for firms and markets. Actual interactions between a company and its suppliers, customers, or other stakeholders can be located anywhere in this two dimensional space: from long term relationships to spot market transactions, and from contractual specification to innovative co-creation (Palmer 2002). It may be noted that in this two-dimensional space the neo-liberal ideal market of autonomous competition and the actual industrial market that is dominated by oligopolistic or monopolistic competition are positioned in different, though adjacent, quarters.

A governance system coordinates behaviour by influencing the behavioural choices of its subjects. A governance system influences these behavioural choices by applying an array of positive and negative incentives, often likened to carrots and sticks (Rothschild 1999). Any governance system is embedded in a social matrix of institutionalised norms, beliefs, and conventions (Biggart, Beamish 2003; Diaz-Bone 2009; Layton 2011). This institutional environment, or social paradigm (Kilbourne et al. 2009; Weiss, Bonvillian 2013), provides various beliefs about which goals are worth pursuing and which behaviours are legitimate ways of goal pursuit, and about which outcomes are legitimate rewards. It is likely that none of these beliefs have a general or universal validity, because the institutional environment normatively limits legitimate goals, legitimate actions, and legitimate incentives (valid carrots and sticks) to a given social context and a given social domain (Diaz-Bone 2009; Granovetter 1985). Within a single institutional environment different governance structures can rely on different sets of incentives to influence the behaviour that people choose to perform in a given context.

The efficiency of market or firm as governance mechanism is known to depend on a particular context, but also the legitimacy or appropriateness of a specific governance mechanism depends on the situational context. Next to markets and firms alternative governance systems for economic transactions may be, e.g., networks, cooperatives, reciprocity, plan-economy, or social anarchy (Coase 1937; Demil, 
Lecocq 2006; Haase et al. 2018; Kropotkin 1927; Powell 1990; Williamson 1995). Each governance system is mediating between the institutional environment and the coordinated behaviour of different actors. Each governance system coordinates the behaviour of people by offering a mix of goals and incentives, but the social domain and the social context determine which incentives and which goals are (legally and/or morally) justifiable (Boltanski, Thévenot 1991). Depending on the social domain and the context the act of offering money to someone can be a payment, a bonus, a tip, a bribe, an insult, or a gift. Apparently the different contexts with their moral or legal implications are not unambiguously demarcated, as evident from the recurring incidents of indictments and litigations (Hummel et al. 2018).

Companies coordinate their behaviour with a range of stakeholders, and companies operate at the intersection of various social domains and social contexts. Therefore economic and non-economic transactions are compromises between different governance systems that rely on different incentive schemes (Finch et al. 2017; Thévenot 2001), and that represent different institutional realities (Demil, Lecocq 2006). Only a part of these transactions happen in a social domain that allows coordination by markets, and within this domain different marketing systems may govern these transactions differently depending on the social context (Layton 2015). Companies may employ a range of governance systems in different markets, to different suppliers, or to different customers. Within a company different employees therefore have different views of the dominant governance system of the firm, and at a higher level of analysis different actors within a value chain have different views of the governance system in that chain, depending on their specific context.

\subsection{Shifting costs within the system}

The governance of firms and marketing systems concerns the exchange of costs and benefits with the system environment, and the distribution of costs and benefits among the system components. Each marketing system, or marketing subsystem, can be analysed in terms of what it does for the market actors and in terms of what it does for other stakeholders. The purpose of a marketing system is what it does, including what it does to actors who are not directly involved in the marketing transactions of that system. 
The productive activities of a firm - and of the value chain of which the firm is a part - can be summarised as coordinating the processes of appraising and tapping resources, and of transforming these into value proposals. A firm creates value proposals by consuming resources, which implies costly processes of acquisition, use, and disposal. All production comes at a cost, and some of these costs are (at least partially) borne by the firm and covered by the price of the offered value proposal. Some of these costs are shifted outside the firm, and at a macro level these costs of production should be outweighed by the benefits of the products in order for welfare to be created. Corporate social responsibility and sustainable management commonly refer to the triple bottom line as a framework to report sustainable performance (Elkington 1997; Hammond 2006; Zwetsloot 2003). The joint consideration of economic, social and ecological costs of production in itself offers little guidance to find an acceptable balance between corporate profit and social costs. The outcome of this balance depends critically on how the usefulness of the good and how the nuisances of the bad are valuated and how the benefits of the good and the costs of the bad are distributed, as worded in an oft-quoted Anglo-Norman legal ruling that "le utility del chose excusera le noisomeness del stink" (Coase 1960). Changing insights on the utility of the production or on the harm of the externalised costs may (and should) imply that the social or public acceptability of specific externalities will change over time, which is in essence a political issue that is covered by stakeholder theory. If stakeholders can combine the power, the urgency and the legitimacy to act then the firm will have to adapt to their needs or face the consequences. At this point it also can be noted that a political-economy in which profits are privatised and costs are socialised is essentially a kleptocracy (Dawisha 2015). Likewise any business that maximises its profit while shifting the burden of environmental costs and social injustice to tax-payers contributes to a system of kleptonomy rather than sustainable development.

Shifting costs of production outside the firm also has systemic consequences beyond the stakeholder model. All production comes at a cost. Some of these costs are shifted outside the firm, and that implies that one of the purposes of that firm is creating costs to the higher-order system of which it is part (Bailey 2005). These costs are absorbed by that higher-order system or shifted up to an even higher-level system 
of which this higher-order system itself is part. Any system that cannot absorb the costs and that cannot shift the costs up must collapse (Bailey 2008). A firm is part of a value chain within a range of marketing systems within a society within a planetary socio-economic system within a planetary ecosystem (Ulrich 1993). Each of these consecutive systems has some absorbency, depending on its capacity to turn the disposals of one subsystem into resources for another and its capacity to maintain balanced interdependencies between its subsystems.

The environment of a company consists of a wide variety of marketing and nonmarketing systems. Each of these systems in the interaction with the firm can become a resource and/or a sink for the firm (Peach, Constantin 1972; Vargo, Lusch 2004). Because resources can be defined as perceived means of attaining valued ends, any change in the desirability of ends - be it at firm level or at societal level - and any innovation in the appraisal of resources may imply that existing resources become liabilities or costs. This explains that incumbent firms often exert considerable effort to thwart societal or technological change. If these firms have concentrated sufficient market power to become oligopolies or (de facto) monopolies, or if these firms manage to harness government support for their private vested interests, they can create "legacy sectors". Legacy sectors are sectors of the economy that effectively block investments, research, technology, or opinions that may threaten the dominant business model, like e.g. global agribusiness or energy (Weiss, Bonvillian 2013).

\section{Digestif: discussion}

The purpose of a system is what the system does, and at the end of this course should be able to explain the purpose of a firm within its market system, positive and negative, in as much detail as possible. The key of teaching sustainable marketing is initiating a lasting change in the way students think about firms and markets in a society. In order to achieve such a change of paradigm "how" critical sustainable reflection is taught is more important than "what" is taught. Most MBA programs teach mainstream theories in order to imprint students with the proverbial myopic profit focus. This implies that any graduate with a critical, sustainable, and deviant 
focus is likely to be challenged by the established mainstream "truths" of, e.g., neoliberal corporatism. The most effective way to prepare students for this opposition would seem to be using these same mainstream theories to challenge the myopic profit focus, and to support a sustainable business focus. One can only reflect meaningfully on what one knows.

Sustainability is not a goal (Marcuse 1998), but sustainable development is an open ended process of identifying and managing social and ecological constraints to economic activity. Because these constraints emerge and unfold over time companies may find at any moment that established resources and practices have lost their value and their legitimacy. The simple fact that an industry has invested all in exploiting a resource on which it depends, is not (and never has been in history) a guarantee for the future. In order to meet the unknown future requirements of sustainable marketing graduates should be able to reflect critically on what they think they know. This new way of thinking only can be learned by doing. The described course shows that students can learn critical reflection by practising on the theoretical and performative knowledge of the received management view.

Education for sustainable development is supposed to be disenchanting, empowering, and system-oriented. The described course shows that this can be achieved by questioning the assumptions of, e.g., resource advantage theory and the consequent marketing orientation relative to the market system and external stakeholders. Especially the observation that social costs create stakeholders can be disenchanting, and triggers a shift away from business centred thinking. Education for sustainable development should be built on systemic and holistic thinking, integration of different perspectives, and self-transcendent values. The described course shows that this can be achieved by subsequent shifts in focus, starting with the individual in the firm and ending with societies and ecosystems. In this shifting focus students are triggered to challenge assumptions of marketing and economics, which inevitable leads to challenging their own and each other's assumptions and worldviews. 


\section{Epilogue}

Managing the sustainable shift in business has been likened to learning a foreign language in an unaccommodating setting (van Dam 2016b). The language we speak influences the way we perceive the world, so if we want to perceive the world differently we need another language. The radical proposal to enforce a language of sustainability is to eliminate the language of neo-classical economics and neoliberalism by eliminating business education (Wymer, Rundle-Thiele 2017). In this paper I have proposed a moderate approach by making students question the established language of business. Merely acknowledging the possibility of less unsustainable marketing systems already requires a holistic approach. This holistic approach appreciates the embeddedness of the company in a network of human and non-human stakeholders and the balancing act of governing the interactions with these stakeholders successfully. Sustainable marketing requires integration of sustainability throughout the company, and values long term continuity over short term profit (Bridges, Wilhelm 2008). In fact any focus on short term profit that jeopardizes continuity is bad business, so it is not too difficult to make students reflect on the semantics and syntax of "profit" in business language. From this point onwards additional shifts in the language of business gradually become more easy. The sustainability of marketing action is inversely related to the social costs of the unintended and/or unacknowledged consequences of goal directed behaviour (Van Dam 2016a). Showing that, depending on one's beliefs and paradigms, social costs can be seen as a fact-of-life, as a justifiable strategic decision, or as illegitimate kleptonomy (Coase 1960), turns these unintended consequences into intended oversights. As organisations adapt not only to technical changes, but also to what (they believe) is legitimate (Barber et al. 2014), this forces professional MBA students to reflect on how to prepare themselves and their companies for the future. Whether this course has indeed a long term effect on the students cannot be determined in the few years that it is being offered. Studying these effects by longitudinal studies may require more graduates than currently available, so it is possible that we'll never know for sure - which applies to much education. This notwithstanding, the presented framework of embedding strategic management of the firm in marketing systems, in 
governance styles, and in institutional theory, assists students in developing their own sustainable marketing orientation. Because sustainable development is an open ended process, teaching students to reflect on what to avoid may be the best preparation for sustainable business careers. Insights on how to avoid it, and what to do instead, develop so fast that they will have to reinvent this for themselves time and again.

\section{References}

Alvesson M., Willmott H. (2002), Identity regulation as organizational control. Producing the appropriate individual, „Journal of Management Studies”, vol. 39 no. 5, pp. 619-644.

Alvesson M., Bridgman T., Willmott H. (2009), The Oxford handbook of critical management studies, Oxford Handbooks, Oxford.

Alvesson M., Sandberg J. (2011), Generating research questions through problematization, „Academy of Management Review", vol. 36 no. 2, pp. 247-271.

Alvesson M., Spicer A. (2012), A stupidity-based theory of organizations, „Journal of Management Studies", vol. 49 no. 7, pp. 1194-1220.

Arndt J. (1981), The political economy of marketing systems. Reviving the institutional approach, „Journal of Macromarketing”, vol. 1 no. 2, pp. 36-47.

Baden D., Higgs M. (2015), Challenging the perceived wisdom of management theories and practice, „Academy of Management Learning and Education”, vol. 14 no. 4, pp. 539-555.

Bailey K.D. (2005), Beyond system internals. Expanding the scope of living systems theory, „Systems Research and Behavioral Science", vol. 22 no. 6, pp. 497-508.

Bailey K.D. (2008), Boundary maintenance in Living Systems Theory and Social Entropy Theory, „Systems Research and Behavioral Science”, vol. 25 no. 5, pp. 587-597.

Barber N.A., Wilson F., Venkatachalam V., Cleaves S.M., Garnham J. (2014), Integrating sustainability into business curricula. University of New Hampshire case study, „International Journal of Sustainability in Higher Education", vol. 15 no. 4, pp. 473-493.

Beddewela E., Warin C., Hesselden F., Coslet A. (2017), Embedding responsible management education - Staff, student and institutional perspectives, „International Journal of Management Education”, vol. 15 no. 2, pp. 263-279.

Beer S. (1981), Brain of the firm. The managerial cybernetics of organization, 2nd ed., J. Wiley, Chichester (UK) - New York.

Beer S. (2002), What is cybernetics?, „Kybernetes”, vol. 31 no. 2, pp. 209-219.

Boltanski L., Thévenot L. (1991), De la justification. Les économies de la grandeur, Gallimard, Paris. 


\section{COOKING UP A COURSE: TEACHING SUSTAINABLE MARKETING AT MBA.}

Borin N., Metcalf L. (2010), Integrating sustainability into the marketing curriculum. Learning activities that facilitate sustainable marketing practices, „Journal of Marketing Education”, vol. 32 no. 2, pp. 140154.

Bridges C.M., Wilhelm W.B. (2008), Going beyond green. The "why and how" of integrating sustainability into the marketing curriculum, „Journal of Marketing Education”, vol. 30 no. 1, pp. 33-46.

Brooks M.A. (2009), Medical education and the tyranny of competency, „Perspectives in Biology and Medicine", vol. 52 no. 1, pp. 90-102.

Burns H. (2009), Skilled in sustainability - teaching sustainability in skills based courses, in: Sustainability at universities - opportunities, challenges and trends, ed. Leal Filho W., Peter Lang GmbH, Frankfurt am Main, pp. 195-206.

Burton D. (2001), Critical marketing theory. The blueprint?, „European Journal of Marketing”, vol. 35 no. 5-6, pp. 722-743.

Campbell D.T. (1976), Assessing the impact of planned social change, The Public Affairs Center, Dartmouth College, Hanover, NH.

Capra F., Luisi P.L. (2014), The systems view of life, Cambridge University Press, Cambridge.

Carson S.J., Devinney T.M., Dowling G.R., John G. (1999), Understanding institutional designs within marketing value systems, „Journal of Marketing”, vol. 63 suppl., pp. 115-130.

Coase R.H. (1937), The nature of the firm, „Economica”, vol. 4 no. 16, pp. 386-405.

Coase R.H. (1960), The problem of social cost, „Journal of Law and Economics”, vol. 3 no. 1, pp. 1-44.

Dawisha K. (2015), Putin's kleptocracy. Who owns Russia?, Simon and Schuster, New York.

Deci E.L., Ryan R.M. (1985), Intrinsic motivation and self-determination in human behavior, Plenum, New York.

Deci E.L., Ryan R.M. (2000), The "what" and "why" of goal pursuits. Human needs and the selfdetermination of behavior, „Psychological Inquiry”, vol. 11 no. 4, pp. 227-268.

Deci E.L., Ryan R.M. (2008), Self-determination theory. A macrotheory of human motivation, development, and health, „Canadian Psychology”, vol. 49 no. 3, pp. 182-185.

Demil B., Lecocq X. (2006), Neither market nor hierarchy or network. The emergence of bazaar governance, „Organization Studies”, vol. 27 no. 10, pp. 1447-1466.

Deshpandé R., Farley J.U., Webster Jr F.E. (1993), Corporate culture, customer orientation, and innovativeness in Japanese firms. A quadrad analysis, „The Journal of Marketing”, vol. 57 no. 1, pp. 2337.

Dewey J. (1938), Logic. The theory of inquiry, Holt, Rinehart and Winston, New York.

Diaz-Bone R. (2009), Konvention, Organisation und Institution. Der institutionentheoretische Beitrag der "Économie des conventions”, „Historical Social Research”, vol. 34 no. 2, pp. 235-264. 
Ehrensal K.N. (2001), Training capitalism's foot soldiers, in: The hidden curriculum in higher education, ed. Margolis E., Routledge, New York - London, pp. 97-113.

Elkington J. (1997), Cannibals with forks. The triple bottom line of 21st century business, Capstone, Oxford.

Ellickson P.B. (2006), Quality competition in retailing. A structural analysis, „International Journal of Industrial Organization”, vol. 24 no. 3, pp. 521-540.

Exter N., Grayson D., Maher R. (2013), Facilitating organizational change for embedding sustainability into academia. A case study, ,Journal of Management Development”, vol. 32 no. 3, pp. 319-332.

Fearne A., Fowler N. (2006), Efficiency versus effectiveness in construction supply chains. The dangers of "lean” thinking in isolation, „Supply Chain Management. An International Journal”, vol. 11 no. 4, pp. 283-287.

Finch J.H., Geiger S., Harkness R.J. (2017), Marketing and compromising for sustainability. Competing orders of worth in the North Atlantic, „Marketing Theory”, vol. 17 no. 1, pp. 71-93.

Fisher J., Bonn I. (2017), Sustainability and undergraduate management curricula. Changes over a 5-year period, „Australian Journal of Environmental Education”, vol. 33 no. 1, pp. 18-33.

Fisk G. (1967), Marketing systems. An introductory analysis, Harper \& Row, New York.

Fournier V., Grey C. (2000), At the critical moment. Conditions and prospects for critical management studies, „Human Relations”, vol. 53 no. 1, pp. 7-32.

Friedman M. (1962), Capitalism and freedom, University of Chicago Press, Chicago.

Friel T., McLaughlin J. (2013), Trends in bringing sustainability and climate change content into the curriculum, in: Recognizing excellence in business education, vol. 3, eds. Craven A.E., Mays L.S., ACBSP, Overland Park, KS, pp. 86-97.

Granovetter M. (1985), Economic action and social structure. The problem of embeddedness, „American Journal of Sociology", vol. 91 no. 3, pp. 481-510.

Grant J. (1999), The incapacitating effects of competence. A critique, „Advances in Health Sciences Education”, vol. 4 no. 3, pp. 271-277.

Grey C., Willmott H. (2005), Critical management studies. A reader, Oxford University Press, Oxford.

Haase M., Becker I., Pick D. (2018), Alternative economies as marketing systems? The role of value creation and the criticism of economic growth, ,Journal of Macromarketing”, vol. 38 no. 1, pp. 57-72.

Habermas J. (1968), Technik und wissenschaft als “Ideologie”, Suhrkamp, Frankfurt am Main.

Hammond G.P. (2006), "People, planet and prosperity". The determinants of humanity's environmental footprint, „Natural Resources Forum”, vol. 30 no. 1, pp. 27-36. 


\section{COOKING UP A COURSE: TEACHING SUSTAINABLE MARKETING AT MBA.}

Hempel C.G. (1980), Comments on Goodman's ways of worldmaking, „Synthese”, vol. 45 no. 2, pp. 193-199.

Hummel K., Pfaff D., Rost K. (2018), Does economics and business education wash away moral judgment competence?, „Journal of Business Ethics”, vol. 150 no. 2, pp. 559-577.

Hunt S.D. (1976), The nature and scope of marketing, ,Journal of Marketing”, vol. 40 no. 3, pp. 17-28.

Hunt S.D., Morgan R.M. (1995), The comparative advantage theory of competition, „The Journal of Marketing”, vol. 59, pp. 1-15.

Hunt S.D., Morgan R.M. (1996), The resource-advantage theory of competition. Dynamics, path dependencies, and evolutionary dimensions, „Journal of Marketing”, vol. 60 no. 4, pp. 107-114.

Hunt S.D. (1997a), Resource-advantage theory and the wealth of nations. Developing the socioeconomic research tradition, ,Journal of Socio-Economics”, vol. 26 no. 4, pp. 335-357.

Hunt S.D. (1997b), Resource-advantage theory. An evolutionary theory of competitive firm behavior?, „Journal of Economic Issues”, vol. 31 no. 1, pp. 59-77.

Hunt S.D., Davis D.F. (2008), Grounding supply chain management in resource-advantage theory, „Journal of Supply Chain Management”, vol. 44 no. 1, pp. 10-21.

Hyland T. (1993a), Competence, knowledge and education, ,Journal of Philosophy of Education”, vol. 27 no. 1, pp. 57-68.

Hyland T. (1993b), Professional development and competence-based education, „Educational Studies”, vol. 19 no. 1 , pp. 123-132.

Hyman M.R. (2004), Revising the structural framework for marketing management, „Journal of Business Research”, vol. 57 no. 9, pp. 923-932.

Jamrozy U. (2007), Marketing of tourism. A paradigm shift toward sustainability, „International Journal of Culture, Tourism and Hospitality Research", vol. 1 no. 2, pp. 117-130.

Jonson E.P., McGuire L.M., O’Neill D. (2015), Teaching ethics to undergraduate business students in Australia. Comparison of integrated and stand-alone approaches, „Journal of Business Ethics”, vol. 132 no. 2, pp. 477-491.

Kilbourne W.E., Dorsch M.J., McDonagh P., Urien B., Prothero A., Grünhagen M., Polonsky M.J., Marshall D., Foley J., Bradshaw A. (2009), The institutional foundations of materialism in Western societies, „Journal of Macromarketing”, vol. 29 no. 3, pp. 259-278.

Kim N., Shin S., Min S. (2016), Strategic marketing capability. Mobilizing technological resources for new product advantage, ,Journal of Business Research”, vol. 69 no. 12, pp. 5644-5652.

King S. (1985), Has marketing failed, or was it never really tried?, „Journal of Marketing Management”, vol. 1 no. $1-2$, pp. 1-19. 
Koris R., Örtenblad A., Ojala T. (2017), From maintaining the status quo to promoting free thinking and inquiry. Business students' perspective on the purpose of business school teaching, „Management Learning", vol. 48 no. 2, pp. 174-186.

Kotler P. (1994), Marketing management, 8th ed., Prentice Hall, Englewood Cliffs, NJ.

Kotler P., Armstrong G., Harris L.C., Piercy N. (2013), Principles of marketing, 6th European ed., Pearson, Harlow.

Kotler P., Keller K.L. (2016), Marketing management, Pearson, Boston.

Kropotkin P. (1927), Anarchism. A collection of revolutionary writings, Courier Corporation, North Chelmsford, MA.

Kurucz E.C., Colbert B.A., Marcus J. (2014), Sustainability as a provocation to rethink management education. Building a progressive educative practice, „Management Learning”, vol. 45 no. 4, pp. 437457.

Layton R.A. (2007), Marketing systems - A core macromarketing concept, „Journal of Macromarketing", vol. 27 no. 3, pp. 227-242.

Layton R.A. (2011), Towards a theory of marketing systems, „European Journal of Marketing”, vol. 45 no. 1 , pp. 259-276.

Layton R.A. (2015), Formation, growth, and adaptive change in marketing systems, „Journal of Macromarketing", vol. 35 no. 3, pp. 302-319.

Lester S., Religa J. (2017), "Competence" and occupational standards. Observations from six European countries, „Education and Training”, vol. 59 no. 2, pp. 201-214.

Leyel C.F., Hartley O. (1925), The gentle art of cookery, Chatto \& Windus, London.

Mamman A., Saffu K. (1998), Short-termism, control, quick-fix and bottom line. Toward explaining the Western approach to management, ,Journal of Managerial Psychology”, vol. 13 no. pp. 291-308.

Marcuse P. (1998), Sustainability is not enough, „Environment and Urbanization”, vol. 10 no. 2, pp. 103112.

Mencken H.L. (1921), Prejudices, second series, Jonathan Cape, London.

Mezirow J. (1981), A critical theory of adult learning and education, „Adult Education”, vol. 32 no. 1, pp. 3-24.

Mitchell R.K., Agle B.R., Wood D.J. (1997), Toward a theory of stakeholder identification and salience. Defining the principle of who and what really counts, „Academy of Management Review”, vol. 22 no. 4, pp. 853-886.

Mitchell R.W., Wooliscroft B., Higham J. (2010), Sustainable market orientation. A new approach to managing marketing strategy, ,Journal of Macromarketing”, vol. 30 no. 2, pp. 160-170. 


\section{COOKING UP A COURSE: TEACHING SUSTAINABLE MARKETING AT MBA.}

Mosley L., Uno S. (2007), Racing to the bottom or climbing to the top? Economic globalization and collective labor rights, „Comparative Political Studies”, vol. 40 no. 8, pp. 923-948.

Mouzas S. (2006), Efficiency versus effectiveness in business networks, „Journal of Business Research”, vol. 59. no. 10, pp. 1124-1132.

Muijen H. (2004), Integrating value education and sustainable development into a Dutch university curriculum, „International Journal of Sustainability in Higher Education”, vol. 5 no. 1, pp. 21-32.

Neurath O. (1932), Protokollsätze, „Erkenntnis”, vol. 3 no. 1, pp. 204-214.

Ng E.S., Burke R.J. (2010), Predictor of business students' attitudes toward sustainable business practices, „Journal of Business Ethics”, vol. 95 no. 4, pp. 603-615.

Nicholls J., Hair Jr J.F., Ragland C.B., Schimmel K.E. (2013), Ethics, corporate social responsibility, and sustainability education in AACSB undergraduate and graduate marketing curricula. A benchmark study, ,Journal of Marketing Education”, vol. 35 no. 2, pp. 129-140.

North D.C. (1984), Government and the cost of exchange in history, „The Journal of Economic History”, vol. 44 no. 12 , pp. $255-264$.

Örtenblad A., Koris R., Farquharson M., Hsu S.W. (2013), Business school output. A conceptualisation of business school graduates, „International Journal of Management Education”, vol. 11 no. 2, pp. 8592.

Overton J., Murray W.E., Banks G. (2012), The race to the bottom of the glass? Wine, geography, and globalization, „Globalizations”, vol. 9 no. 2, pp. 273-287.

Palazzo G., Krings F., Hoffrage U. (2012), Ethical blindness, „Journal of Business Ethics”, vol. 109 no. 3, pp. 323-338.

Palmer A. (2002), Cooperative marketing associations. An investigation into the causes of effectiveness, „Journal of Strategic Marketing”, vol. 10 no. 2, pp. 135-156.

Peach W.N., Constantin J.A. (1972), Zimmermann's world resources and industries, 3rd ed., Harper \& Row, New York.

Perera C.R., Hewege C.R. (2016), Integrating sustainability education into international marketing curricula, „International Journal of Sustainability in Higher Education”, vol. 17 no. 1, pp. 123-148.

Phelan S.E. (2006), Propaganda model of business school behavior, „Quarterly Journal of Ideology”, vol. 29. no. 1-2, pp. 1-19.

Porter M.E. (1985), Competitive advantage. Creating and sustaining superior performance, Free Press, New York.

Posner R.A. (2007), Economic analysis of law, 7th ed., Aspen Publishers, New York, NY.

Powell W.W. (1990), Neither market nor hierarchy. Network forms of organization, „Research in Organizational Behavior", vol. 12, pp. 295-336. 
Priddle J. (1994), Marketing ethics, macromarketing, and the managerial perspective reconsidered, „Journal of Macromarketing”, vol. 14 no. 2, pp. 47-62.

Robinson P. (2009), Teaching urban sustainability - new approaches for emerging needs, in: Sustainability at universities - opportunities, challenges and trends, ed. Leal Filho W., Peter Lang GmbH, Frankfurt am Main, pp. 109-120.

Rothschild M.L. (1999), Carrots, sticks, and promises. A conceptual framework for the management of public health and social issue behaviors, „Journal of Marketing”, vol. 63 no. 4, pp. 24-37.

Roy A., Macchiette B. (2005), Debating the issues. A tool for augmenting critical thinking skills of marketing students, „Journal of Marketing Education”, vol. 27 no. 3, pp. 264-276.

Ryan R.M., Deci E.L. (2000), Self-determination theory and the facilitation of intrinsic motivation, social development, and well-being, „American Psychologist”, vol. 55 no. 1, pp. 68-78.

Saren M., Maclaran P., Goulding C., Elliott R., Shankar A., Catterall M. (2007), Critical marketing. Defining the field, Butterworth-Heinemann, Oxford.

Schneiderman D., Freihoefer K. (2009), Integrating sustainability into design curriculum, in: Sustainability at universities - opportunities, challenges and trends, ed. Leal Filho W., Peter Lang GmbH, Frankfurt am Main, pp. 241-256.

Schwartz B. (2012), Crowding out morality. How the ideology of self-interest can be self-fulfilling, in: Ideology, psychology, and law, ed. Hanson J., Oxford University Press, Oxford, pp. 160-184.

Smith W.J. (1994), Comment on "Of Dinosaurs and Sacred Cows: The Grading of Classroom Participation”, „Journal of Management Education”, vol. 18 no. 2, pp. 237-240.

Snelson-Powell A., Grosvold J., Millington A. (2016), Business school legitimacy and the challenge of sustainability. A fuzzy set analysis of institutional decoupling, „Academy of Management Learning and Education”, vol. 15 no. 4, pp. 703-723.

Spicer A., Alvesson M., Kärreman D. (2009), Critical performativity. The unfinished business of critical management studies, „Human Relations”, vol. 62 no. 4, pp. 537-560.

Svanström M., Lozano-García F.J., Rowe D. (2008), Learning outcomes for sustainable development in higher education, „International Journal of Sustainability in Higher Education”, vol. 9 no. 3, pp. 339351.

Tadajewski M., Brownlie D.T. (2008), Critical marketing. Contemporary issues in marketing, Wiley, Chichester.

Tadajewski M. (2010a), Critical marketing studies. Logical empiricism, "critical performativity" and marketing practice, ,Marketing Theory”, vol. 10 no. 2, pp. 210-222.

Tadajewski M. (2010b), Towards a history of critical marketing studies, „Journal of Marketing Management", vol. 26 no. 9-10, pp. 773-824.

Tarrant J. (2000), What is wrong with competence? , „Journal of Further and Higher Education”, vol. 24 no. 1 , pp. $77-83$. 


\section{COOKING UP A COURSE: TEACHING SUSTAINABLE MARKETING AT MBA.}

Tarrant S.P., Thiele L.P. (2016), Practice makes pedagogy - John Dewey and skills-based sustainability education, „International Journal of Sustainability in Higher Education”, vol. 17 no. 1, pp. 54-67.

Thévenot L. (2001), Organized complexity. Conventions of coordination and the composition of economic arrangements, „European Journal of Social Theory”, vol. 4 no. 4, pp. 405-425.

Turnquist P.H., Bialaszewski D.W., Franklin L. (1991), The undergraduate marketing curriculum. A descriptive overview, „Journal of Marketing Education”, vol. 13 no. 1, pp. 40-46.

Ulrich W. (1993), Some difficulties of ecological thinking, considered from a critical systems perspective. A plea for critical holism, „Systems Practice”, vol. 6 no. 6, pp. 583-611.

Van Dam Y.K., Apeldoorn P.A.C. (1996), Sustainable marketing, „Journal of Macromarketing”, vol. 16 no. 2, pp. 45-56.

Van Dam Y.K. (2016a), The seductive logic of subtractive sustainability. Reflections on sustainable socio-economic development, „The Central European Review of Economics and Management”, vol. 16 no. 4, pp. 19-30.

Van Dam Y.K. (2016b), Learning to speak Dutch in the Netherlands, in: Macromarketing and academic activism, ed. Campbell N., Claudy M., O’Driscoll A., The Macromarketing Society, Laramie, WY, pp. 373-392.

Van Dam Y.K., Van Trijp H.C.M. (2016), Interventions to encourage sustainable consumption, „APSTRACT: Applied Studies in Agribusiness and Commerce”, vol. 10 no. 2-3, pp. 51-58.

Vargo S.L., Lusch R.F. (2004), Evolving to a new dominant logic for marketing, „Journal of Marketing”, vol. 68 no. 1 , pp. 1-17.

Vargo S.L. (2011), Market systems, stakeholders and value propositions. Toward a service-dominant logic-based theory of the market, „European Journal of Marketing”, vol. 45 no. 1/2, pp. 217-222.

Velasco Arias G. (2019), Crítica del critical thinking. Un análisis de la transformación del significado ilustrado de "crítica” en el discurso empresarial sobre la educación, „Prisma Social”, vol. 25, pp. 277298.

Wals A.E. (2012), Shaping the education of tomorrow. 2012 full-length report on the UN decade of education for sustainable development, Unesco, Paris.

Weiss C., Bonvillian W.B. (2013), Legacy sectors. Barriers to global innovation in agriculture and energy, „Technology Analysis and Strategic Management”, vol. 25. no. 10, pp. 1189-1208.

Wiek A., Withycombe L., Redman C. L. (2011), Key competencies in sustainability: A reference framework for academic program development, „Sustainability Science”, vol. 6 no. 2, pp. 203-218.

Wieland J.R., Fitzgibbons D.E. (2013), Integrating corporate sustainability and organizational strategy within the undergraduate business curriculum, „Organisation Management Journal”, vol. 10 no. 4, pp. 255-266. 
Wilhelm P.G. (2002), International validation of the corruption perceptions index. Implications for business ethics and entrepreneurship education, ,Journal of Business Ethics”, vol. 35 no. 3, pp. 177-189.

Wilkie W.L., Moore-Shay E.S. (1997), Consortium survey on marketing and society issues. Summary and results, „Journal of Macromarketing”, vol. 17 no. 2, pp. 89-95.

Wilkie W.L. (2016), Reflections on marketing and imagination, „AMS review”, vol. 6 no. 3-4, pp. 125131.

Williamson O.E. (1995), Hierarchies, markets and power in the economy. An economic perspective, „Industrial and Corporate Change”, vol. 4 no. 1, pp. 21-49.

Williamson O.E. (2002), The theory of the firm as governance structure. From choice to contract, „Journal of Economic Perspectives”, vol. 16 no. 3, pp. 171-195.

Wymer W., Rundle-Thiele S.R. (2017), Inclusion of ethics, social responsibility, and sustainability in business school curricula. A benchmark study, „International Review on Public and Nonprofit Marketing”, vol. 14 no. 1, pp. 19-34.

Zimmermann E.W. (1933), World resources and industries. A functional appraisal of the availability of agricultural and industrial resources, Harper \& Brothers, New York.

Zimmermann E.W. (1951), World resources and industries, 2nd ed., Harper \& Brothers, New York.

Zwetsloot G.I.J.M. (2003), From management systems to corporate social responsibility, „Journal of Business Ethics", vol. 44 no. 2-3, pp. 201-207. 